Gazi University
Journal of Science
$\mathrm{http} / /$ dergipark.gov.tr/gujs

\title{
A Reclamation Model for Post-Mining Marble Quarries
}

\author{
Nihat Cagil CINAR ${ }^{1, *}$ (D) Ebru Vesile OCALIR ${ }^{2}$ (D) \\ ${ }^{I}$ Gazi University, Graduate School of Natural and Applied Sciences, Department of Environmental and Technical Research of Accidents, 06500, \\ Ankara, Turkey \\ ${ }^{2}$ Gazi University, Faculty of Architecture, City and Regional Planning, 06570, Ankara, Turkey
}

\section{Highlights}

- In this study, a land use suitability model is developed as a decision support tool.

- The objective of the model is to find out the best land use alternative for post-mining areas.

- The model was tested in Burdur-Antalya-Isparta provinces of Turkey.

- Thematic maps express the spatial distribution of each most appropriate land use alternative.

- The model results give the best option among the five alternative land use classes.

\section{Article Info}

Received: $27 / 10 / 2018$

Accepted: 01/04/2019

\section{Keywords}

GIS

Post-mining

Land use suitability model

Decision support tool

\begin{abstract}
The damage caused by mining activities are usually environmental aesthetic disturbances (pits and voids), degradation of the existing topographic structure, the pollution of underground and surface water resources, the problems of dust in the living areas, the negativities in terms of life and property safety, the damages of the vital usage areas and the restriction of the living spaces. A methodology has been defined to determine the best future land use alternative for active marble mining sites. GIS, multi-criteria decision making method and fuzzy logic methods are used together to create a land use suitability model as a decision support tool. The study is limited to marble mining activity in the case study of Antalya, Burdur, and Isparta regions (Turkey). The model results give the best option among the alternative land use classes, agricultural areas (A), afforestation (F), recreational area (R), industrial area (I) and landfill area (L) for the 715 marble mines in the study area.
\end{abstract}

\section{INTRODUCTION}

The necessary environmental and technical measures must be taken in the abandoned mining areas. If no precaution is taken, the ecological structure can be subject to great damages and dangerous situations in terms of life and property safety. The damage caused by mining activities, which is mainly result of open pit and underground production methods, are usually environmental aesthetic disturbances (pits and voids), degradation of the existing topographic structure, and the pollution of underground and surface water resources. At the same time, the problems of dust in the living areas, the negativities in terms of life and property safety, the damages of the vital usage areas and the restriction of the living spaces are also important in this context. For this purpose, during the process of production planning of mining areas, rehabilitation plans should also be prepared. In many countries around the world, there are legal regulations and practices in the rehabilitation of mining fields. Examples include [1], the legal practice in the USA which defines obligations for the rehabilitation of mining fields, and [2], which aims at control of surface mining and re-use of mining fields, environmental management, rehabilitation and reforestation of them. Another example is [3], which was published in Australia for rehabilitation plans, recoveries and sustainable environmental targets for mining fields.

A literature review has been carried to define the criteria to determine the post-mining land use of marble quarries. Considering the opinions of the experts, literature review and the previous studies in the sector, 
the criteria which are effective in determining the land use planning of post-mining marble quarries were determined. To determine the land use of the marble quarries in the study area, a land use model consisting of geographic information systems software, multi-criteria decision-making method, fuzzy logic membership functions, and thematic outputs has been formed. Within the scope of the study area, a systematic approach has been developed to determine the future re-use of land for post-mining activities.

\section{LITERATURE REVIEW}

In this study, a methodology for determining the best future land use alternative in existing mining areas for their post-mining situation is defined. GIS, multi-criteria decision making method and fuzzy logic methods are used together to create a land use suitability model as a decision support tool for determining the most suitable land use for post-mining areas. For this purpose, a general literature review on the studies to determine the land use of the area was carried out. After that, a literature review was conducted for determining the post-mining land use type and effective criteria for the abandoned mining sites. In Table 1 , the effective criteria for determining different land use types are summarized. The table is classified under 5 main land use classes; agricultural areas (A), afforestation (F), recreational area $(\mathrm{R})$, industrial area (I) and landfill area (L), as in the literature and gives the effective criteria accordingly.

Table 1. Literature survey on effective criteria of possible land use types for post-mining [4-23]

\begin{tabular}{|c|c|c|c|c|c|}
\hline Land Use & Criteria & Lit. & $\begin{array}{l}\text { Year } \\
\text { of the } \\
\text { study }\end{array}$ & $\begin{array}{l}\text { Method } \\
\text { used }\end{array}$ & $\begin{array}{l}\text { Total area } \\
\text { observed or } \\
\text { Number of } \\
\text { observations }\end{array}$ \\
\hline \multirow[t]{3}{*}{$\begin{array}{l}\text { Agricultural } \\
\text { Area } \\
\text { (A) }\end{array}$} & $\begin{array}{l}\text { Slope, land cover, soil depth, soil texture, soil } \\
\text { moisture, maximum water holding capacity, soil } \\
\text { erosion, soil organic carbon, potential of } \\
\text { hydrogen, nitrogen, phosphorus, potassium. }\end{array}$ & [4] & 2015 & $\begin{array}{l}\text { Analytic } \\
\text { hierarchy } \\
\text { process }\end{array}$ & 42,010 ha \\
\hline & $\begin{array}{l}\text { Soil texture, drainage, soil depth, percentage of } \\
\text { gravel and rock, permeability, slope, flood, } \\
\text { salinity, land slide, erosion, rainfall. }\end{array}$ & {$[5]$} & 2013 & $\begin{array}{l}\text { Linear } \\
\text { combinati } \\
\text { on }\end{array}$ & 8 points \\
\hline & $\begin{array}{l}\text { Great soil group, land use capability, soil depth, } \\
\text { erosion, other soil properties, slope, aspect, } \\
\text { elevation }\end{array}$ & [6] & 2013 & $\begin{array}{l}\text { Analytic } \\
\text { hierarchy } \\
\text { process }\end{array}$ & 231,399 ha \\
\hline \multirow[t]{4}{*}{$\begin{array}{l}\text { Afforestation } \\
\text { (F) }\end{array}$} & $\begin{array}{l}\text { Biodiversity, profitability, regulation capability, } \\
\text { protection potential, aesthetics }\end{array}$ & [7] & 2013 & $\begin{array}{l}\text { Analytic } \\
\text { hierarchy } \\
\text { process }\end{array}$ & 740,000 ha \\
\hline & $\begin{array}{l}\text { Distance from water resources, forest density, } \\
\text { distance from roads, distance from residential } \\
\text { areas, distance from negative factors, distance } \\
\text { from recreational attractive, slope, aspect, } \\
\text { elevation, erosion, soil type, petrology }\end{array}$ & {$[8]$} & 2013 & $\begin{array}{l}\text { Analytic } \\
\text { hierarchy } \\
\text { process }\end{array}$ & $57,027.7$ ha \\
\hline & $\begin{array}{l}\text { Irrigation water use, proximity to canals, canal } \\
\text { density, collector density, ground water table } \\
\text { level, ground water salinity, slope }\end{array}$ & [9] & 2016 & $\begin{array}{l}\text { Fuzzy } \\
\text { modeling }\end{array}$ & 662,042 ha \\
\hline & $\begin{array}{l}\text { Elevation, slope, aspect, relief amplitude, the } \\
\text { distance to rivers, the distance to roads, the } \\
\text { distance to city centers. }\end{array}$ & {$[10]$} & 2017 & $\begin{array}{l}\text { Ecosyste } \\
\text { m service }\end{array}$ & 1337 ha \\
\hline \multirow[t]{2}{*}{$\begin{array}{l}\text { Recreational } \\
\text { Area } \\
(\mathrm{R})\end{array}$} & $\begin{array}{l}\text { Scenic routes, accessibility to the broad water, } \\
\text { proximity to water ways, proximity to natural } \\
\text { protected zones, floodplain areas, fire hazard } \\
\text { area, storm surge, compatibility with surrounding } \\
\text { land uses, existence of infrastructure, site } \\
\text { topography, minimum required area }\end{array}$ & {$[11]$} & 2015 & $\begin{array}{l}\text { Fuzzy } \\
\text { analytic } \\
\text { hierarchy } \\
\text { process }\end{array}$ & 3,458 ha \\
\hline & $\begin{array}{l}\text { Great soil group, Land use capability sub-class, } \\
\text { Land use capability sub-class, Soil depth }\end{array}$ & {$[12]$} & 2013 & $\begin{array}{l}\text { Analytic } \\
\text { hierarchy } \\
\text { process }\end{array}$ & 231,399 ha \\
\hline
\end{tabular}




\begin{tabular}{|c|c|c|c|c|c|}
\hline \multirow[t]{4}{*}{$\begin{array}{l}\text { Industrial } \\
\text { Area } \\
\text { (I) }\end{array}$} & $\begin{array}{l}\text { Distance to water resources, distance to } \\
\text { residential area, distance to road network, slope, } \\
\text { current land use }\end{array}$ & {$[13]$} & 2013 & $\begin{array}{l}\text { Fuzzy } \\
\text { modeling } \\
\text { weighted } \\
\text { linear } \\
\text { combinati } \\
\text { on }\end{array}$ & - \\
\hline & $\begin{array}{l}\text { Terrain elevation, slope, geomorphological type, } \\
\text { engineering geological condition, exposure to } \\
\text { geological hazard, land use type, proximity to } \\
\text { road, proximity to urban built area, population } \\
\text { density, air quality }\end{array}$ & [14] & 2014 & $\begin{array}{l}\text { Ordered } \\
\text { weighting } \\
\text { averaging }\end{array}$ & $1,640,100$ ha \\
\hline & $\begin{array}{l}\text { Altitude, climate, ecology, exposure to sunshine, } \\
\text { geology structure, hydrology, soil, topography, } \\
\text { landscape quality, availability of reclamation, } \\
\text { accessibility, environmental contaminations, size } \\
\text { and shape of the sites, surrounding land use, type } \\
\text { intensity and value of use, changes in livelihood } \\
\text { quality, eco-tourism, employment opportunities, } \\
\text { legislation requirements, location, population } \\
\text { characteristics, consistency with local } \\
\text { requirements. }\end{array}$ & [15] & 2014 & $\begin{array}{l}\text { Fuzzy- } \\
\text { AHP } \\
\text { Fuzzy- } \\
\text { TOPSIS }\end{array}$ & 3,570 ha \\
\hline & $\begin{array}{l}\text { Terrain slope, fertility of the soil, proximity to } \\
\text { lakes, proximity to archeological sites, proximity } \\
\text { to villages }\end{array}$ & [16] & 2017 & $\begin{array}{l}\text { Evolution } \\
\text { ary } \\
\text { algorithm } \\
\text { Optimizat } \\
\text { ion }\end{array}$ & 333 ha \\
\hline \multirow[t]{5}{*}{$\begin{array}{l}\text { Landfill Area } \\
\text { (L) }\end{array}$} & $\begin{array}{l}\text { Fault, slope, surface water and ground water, } \\
\text { soil, geology, main road, side track, rural areas, } \\
\text { land use, urban areas }\end{array}$ & [17] & 2017 & $\begin{array}{l}\text { Analytic } \\
\text { hierarchy } \\
\text { process }\end{array}$ & - \\
\hline & $\begin{array}{l}\text { Distance to surface water resources, distance to } \\
\text { settlements, distance to cities }\end{array}$ & {$[18]$} & 2013 & $\begin{array}{l}\text { Fuzzy } \\
\text { analytical } \\
\text { network } \\
\text { process }\end{array}$ & - \\
\hline & $\begin{array}{l}\text { Distance to water resources, ground water } \\
\text { quality, soil permeability, ground water depth, } \\
\text { distance from faults, distance to city, land cover, } \\
\text { distance from roads, soil depth, distance to } \\
\text { residential area, distance from historical sites, } \\
\text { wind direction }\end{array}$ & [19] & 2015 & $\begin{array}{l}\text { Analytic } \\
\text { hierarchy } \\
\text { process }\end{array}$ & 404,000 ha \\
\hline & $\begin{array}{l}\text { Distance to ground water, distance to surface } \\
\text { water, sensitive ecosystems, land cover, distance } \\
\text { to urban and rural areas, land uses, distance to } \\
\text { roads, slope, soil type, distance to waste } \\
\text { generation places }\end{array}$ & {$[20]$} & 2017 & $\begin{array}{l}\text { Analytic } \\
\text { hierarchy } \\
\text { process }\end{array}$ & 319,500 ha \\
\hline & $\begin{array}{l}\text { Land use, distance from surface water, distance } \\
\text { from road, distance from settlement, distance } \\
\text { from airport, slope, aspect, groundwater table, } \\
\text { flow accumulation, lineament, soil }\end{array}$ & [21] & 2015 & $\begin{array}{l}\text { Analytic } \\
\text { hierarchy } \\
\text { process, } \\
\text { weighted } \\
\text { linear } \\
\text { combinati } \\
\text { on }\end{array}$ & 10,100 ha \\
\hline
\end{tabular}




\begin{tabular}{|l|l|l|l|l|l|}
\hline & $\begin{array}{l}\text { Distance from ground waters, distance from } \\
\text { surface waters, soil texture, soil depth, slope, } \\
\text { distance from fault, land use, distance from } \\
\text { protected areas, distance from urban areas, } \\
\text { distance from villages, distance from main road, } \\
\text { distance from airport, distance from historical } \\
\text { sites, distance from industries }\end{array}$ & {$[22]$} & 2015 & $\begin{array}{l}\text { Analytic } \\
\text { network } \\
\text { process, } \\
\text { ordered } \\
\text { weighting } \\
\text { averaging }\end{array}$ & 342,500 ha \\
\cline { 2 - 5 } & $\begin{array}{l}\text { Subsoil stoniness, subsoil permeability, soil } \\
\text { depth, soil salinity, soil erosion, soil alkalinity, } \\
\text { topsoil texture, slope }\end{array}$ & {$[23]$} & 2015 & $\begin{array}{l}\text { Analytic } \\
\text { hierarchy } \\
\text { process }\end{array}$ & 404,000 ha \\
\hline
\end{tabular}

An approach to the classification of multi-criteria decision-making methods [24] stated that multi-criteria decision-making approaches can be divided into two classes as multi-objective decision making (MODM) and multi-attribute decision making (MADM). In a classification study [25] approach stated that there are two types of multi-criteria decision making method, one of which is not compensating and the other is the compensating method. Another approach [26] stated that multi-criteria decision-making methods can be divided into four main categories; compensatory and non-compensatory methods, rankings, mathematical programming methods, and experimental methods.

\section{METHODOLOGY}

After the literature review of the method classification, in this study multi-criteria decision-making methods were preferred instead of multivariate decision-making methods as the types of land use were specific before the decision-making phase and there was no need to derive land use in this context. It is understood that the balancing methods should be preferred due to the high number of alternative land usage types. Because of the combination of qualitative and quantitative data in determined criteria, it is understood that there is a need to make a group decision by making a double comparison between alternative field uses by decision makers and experts. It is aimed to apply fuzzy logic and analytical network process methods together by taking into account the uncertainties in the knowledge of decision making content, the application areas of the methods in the literature and the acceptability ratios in the studies. Considering the structure of the selected region, expert decisions were made as a result of the literature review, the types of post-mining land use and effective criteria were determined.

The application areas of the methods in the literature and the acceptability ratios of the studies are taken into account in the literature. In this context, the fuzzy logic method was used in determining the membership values of the criteria that are effective in determining the land usage of the post-mining area. Besides, the analytical network process method was applied during the determination of the weights of the mentioned criteria. This paper aims to identify and analyze the land usage of active marble mining areas by taking into account expert opinions, regional structure and protection areas. The whole process applied can be summarized as the scheme shown in Figure 1. 


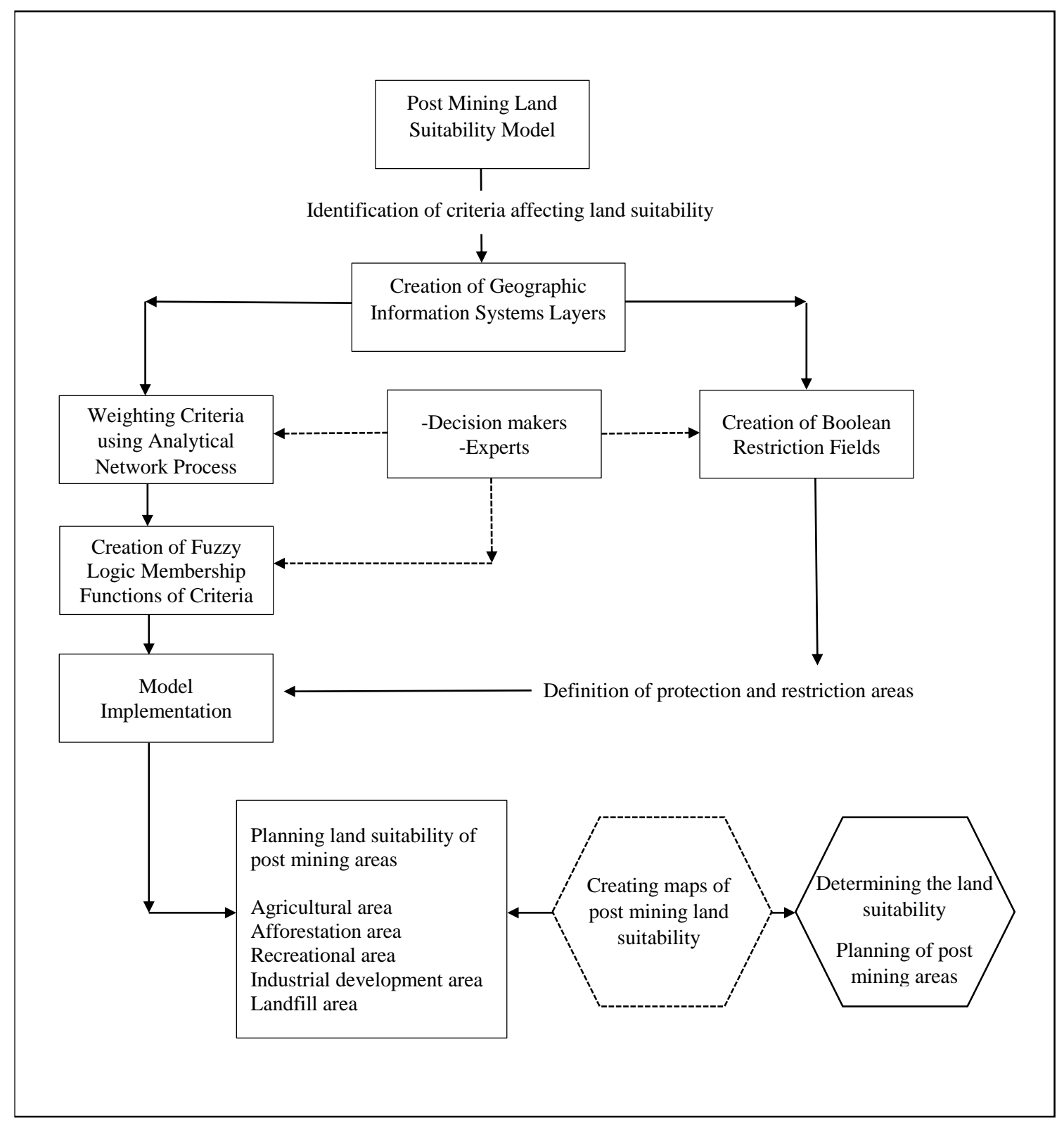

Figure 1. General structure of the land use suitability model

The expectations from the model are;

- define an effective set of criteria for determining the most suitable land use type,

- consolidate the relevant map layers within the study area on the geographic information system,

- identify Boolean protection fields and restriction fields,

- determine the priority weights of the specified criteria, and

- use fuzzy logic in the normalization of the criteria maps, which consist of the membership functions and to prepare the thematic maps.

\subsection{Limitations of the Model}

The model consists of 15 different map layers and a total of 374,492 cells to be analyzed. Normalization of the criteria values for each cell was generated in GIS. The map layers used in the study were assigned to the mathematical values by overlapping the existing marble license areas. In cases where it is necessary to determine the distance between polygons, cell values are determined by creating distance-based values. After combining the map layers within the scope of the study on the geographic information system, $30 \mathrm{~m}$. 
x $30 \mathrm{~m}$. dimension pixel cells were created. When determining the cell size; the size of the selected region, the applicability of the analysis, the approximate areas of the existing marble mining licenses and their number and the limitations of the legal marble license area were taken into account. By using 1/25000 scale topographic maps (Contoured curves at $10 \mathrm{~m}$ period) produced by General Command of Cartography, the slope and elevation values obtained by producing a digital elevation model.

Environmental plans of Burdur, Isparta, and Antalya provinces within the scope of application are obtained from the numerical database of the Ministry of Environment and Urbanization. In the context of the 1938 American soil classification system of the Ministry of Food, Agriculture, and Livestock, the geographic information system data of the land use capability and other soil quality standards determined by the regions were used. The map layers used in this study are given in Table 2 .

Table 2. Map layers used in the study

\begin{tabular}{|l|l|l|l|}
\hline Data type & Map type & Scale & Description \\
\hline $\begin{array}{l}\text { Geographic Information } \\
\text { Systems }\end{array}$ & Vector & - & $\begin{array}{l}\text { MapInfo Professional Discover Bundle } \\
\text { V15,0 software }\end{array}$ \\
\hline Planning area limits & Vector & - & $\begin{array}{l}\text { Existing limits for the entire research area } \\
\text { and the provinces and districts within the } \\
\text { area }\end{array}$ \\
\hline Highway network & Vector & - & Highway network data \\
\hline Environmental plans & Raster & $1 / 100000$ & $\begin{array}{l}\text { Existing land uses, protected areas, zoning } \\
\text { plans, restriction areas, tourism areas etc. } \\
\text { other environmental plans }\end{array}$ \\
\hline Mining license area & Raster & $1 / 25000$ & $\begin{array}{l}\text { Geographical data of mining (marble) and } \\
\text { other natural stone mining licenses data }\end{array}$ \\
\hline Soil structure & Raster & $1 / 25000$ & Soil quality classifications data \\
\hline Digital elevation model & Raster & $1 / 25000$ & $\begin{array}{l}\text { Digital elevation model where topographic } \\
\text { analyzes such as height and slope can be } \\
\text { obtained }\end{array}$ \\
\hline Geographic faults & Vector & $1 / 100000$ & $\begin{array}{l}\text { Geographical data of existing fault } \\
\text { formation }\end{array}$ \\
\hline
\end{tabular}

Expert opinion forms and expert decisions were taken into consideration when defining the criteria affecting the use of a post-mining area, identifying fuzzy membership functions of the criterion values and determination of the criteria weight. A total of 10 academicians and inspectors who have studied the marble quarries in the study area and know the structure of the region have been taken into account. Changes in the results may occur depending on the selection of experts but this process is experienced in the natural structure of multi criteria decision making methods of human nature. To minimize the error in the process of decision making, expert opinion forms were formed and a decision was made as a result of the interviews. Due to the bigger size of the data, model sensitivity analysis could not be performed. The model application results were checked manually by taking into account each field usage type and function type.

\subsection{General Structure of the Land Use Suitability Model}

A spatial model has been established including, priority weights of the criteria and normalization of the criteria by fuzzy logic membership functions and to combine them in the geographical information system environment to determine the land use suitability considering the protection and restriction areas. MapInfo Professional Software is used for GIS.

The final overall land suitability classification is obtained by convex combination method,

$$
w_{l} R_{\imath}+\cdots+w_{n} R_{n}=\sum_{j=1}^{n} w_{j} R_{j}
$$

where $w_{j}$ is the weight value of land use type and $R_{j}$ is the membership value of land use type. 


\subsection{Definition of the Polygon Areas}

Within the scope of the study, the polygon areas to be analyzed by GIS are defined to determine the most suitable land use of post-mining areas within the selected region. $30 \mathrm{~m}$. x $30 \mathrm{~m}$. dimension pixel cells were created to perform the necessary mathematical analyzes after combining the map layers required on the geographical information system. During cell size determination; the size of the selected zone, the applicability of the analysis and the approximate areas of existing mining licenses areas are taken into account. Land use suitability analysis was conducted within the data cells created to match the marble quarry fields in the study area (Figure 2).

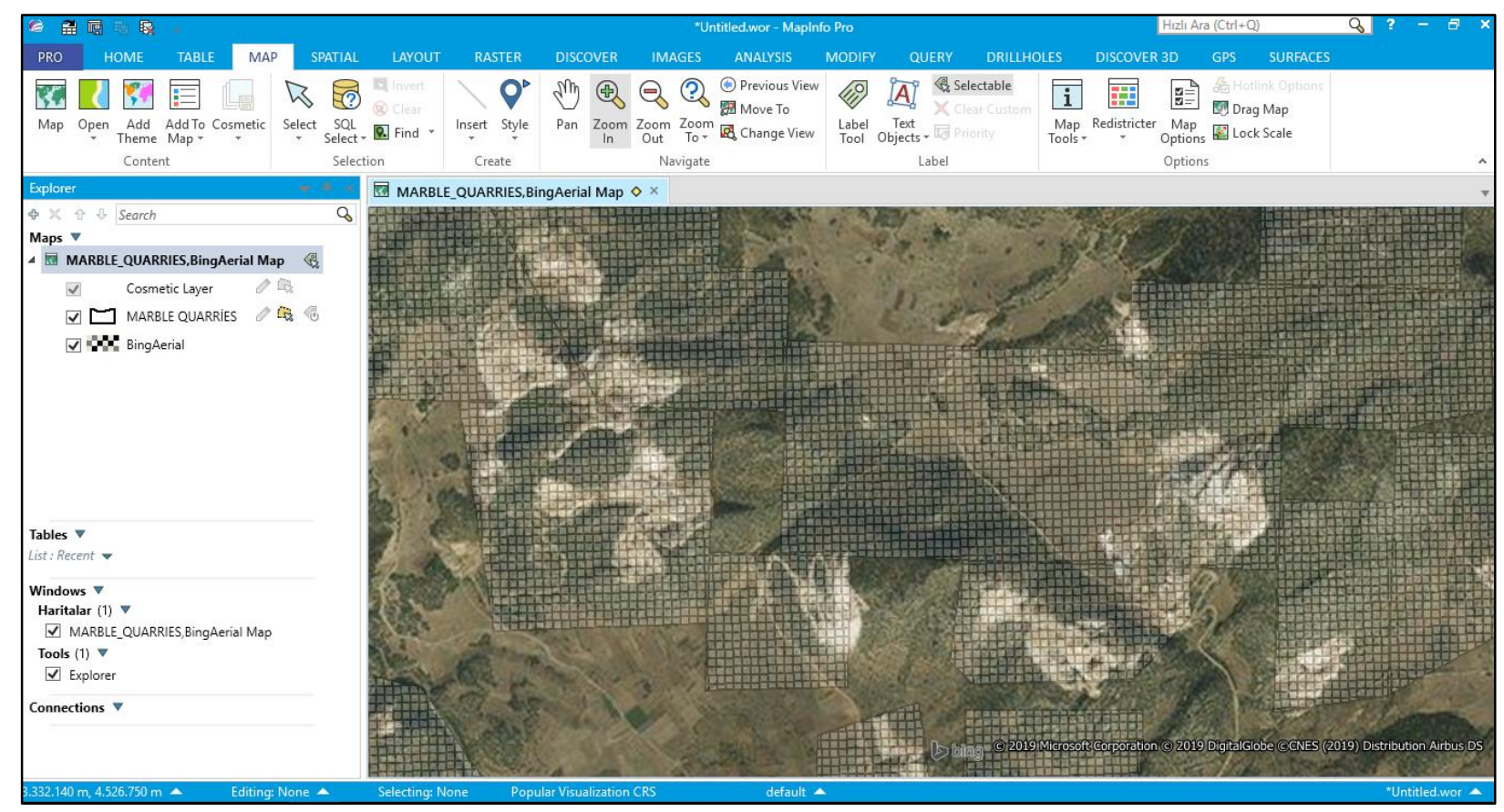

Figure 2. A sample of cells created on the mining license areas

When determining the criterion values of each cell; related map layers were matched with existing marble quarry layers and in some cases, distance based cell values were determined and value assignment process was applied in each cell. It is aimed to determine which of the land use type is most suitable and to determine the importance ratings of the other land use suitability scores in terms of the location of the marble quarries.

\subsection{Definition of Absolute Protection and Restriction Zones in the Study Area}

There are some protection zones in the study area which are defined by related law and regulations (natural and archaeological sites, interaction areas, special environmental protection zones, national parks, wetlands, natural conservation areas, drinking water absolute protection zones, irrigation pond protection zones, underground water resources protection zones, aquifers, dams, lakes and ponds, Eğirdir Lake protection zone, Düden Lake protection zone, coast, beach and beaches, Burdur Lake wildlife improvement area, Karataş Lake wildlife improvement area, tourism areas, etc). By using Boolean intersections, these areas are defined as absolute protected areas in the model and the land use suitability index value is given "0" for them.

Buffers are used to restrict the use of the area and the developed land use suitability analysis was not performed (Table 3). The GIS software's screen output for the absolute protection zones is given in Figure 3. 
Table 3. Absolute protection zones by provinces in the study area

\begin{tabular}{|l|l|l|l|}
\hline \multirow{2}{*}{ ABSOLUTE PROTECTION ZONES } & \multicolumn{3}{l}{ Protection Areas (ha) } \\
\cline { 2 - 4 } & Antalya & Isparta & Burdur \\
\hline Naturel and archaeological sites & $63,062.81$ & $154,678.82$ & $29,623.75$ \\
\hline Interaction areas & 22,040 & $1,694.04$ & $10,094.53$ \\
\hline Special environmental protection zones & $57,334.08$ & - & - \\
\hline City development plan & $91,290.72$ & $46,476.75$ & $18,095.28$ \\
\hline National parks & $75,859.03$ & $65,209.70$ & - \\
\hline Natural parks & $22,510.69$ & $7,731.02$ & 83.33 \\
\hline Wetlands & $7,519.09$ & $62,512.51$ & $87,374.51$ \\
\hline Natural conservation areas & $2,265.60$ & $1,291.74$ & 35.67 \\
\hline Absolute protection areas & $279,120.09$ & $693,048.69$ & $206,067.23$ \\
\hline Drinking water absolute protection zones & $35,491.98$ & $27,665.36$ & $16,315.12$ \\
\hline Irrigation pond protection zones & $43,647.26$ & $215,588.53$ & $100,090.69$ \\
\hline Underground water resources protection zones & $157,369.20$ & $55,718.18$ & $87,831.41$ \\
\hline Lakes and ponds & $24,634.44$ & $378,329.11$ & $218,701.62$ \\
\hline Dams & $134,636.60$ & $4,252.39$ & $6,313.08$ \\
\hline Eğirdir Lake protection zone & - & $72,119.79$ & - \\
\hline Düden Lake protection zone & $7,816.30$ & - & - \\
\hline Coastal zones and beaches & $3,491.24$ & - & 75.43 \\
\hline Burdur Lake wildlife improvement area & - & - & $27,434.72$ \\
\hline Karataş Lake wildlife improvement area, & & & $8,411.84$ \\
\hline Tourism areas & $12,174.38$ & 699.71 & 204.56 \\
\hline
\end{tabular}

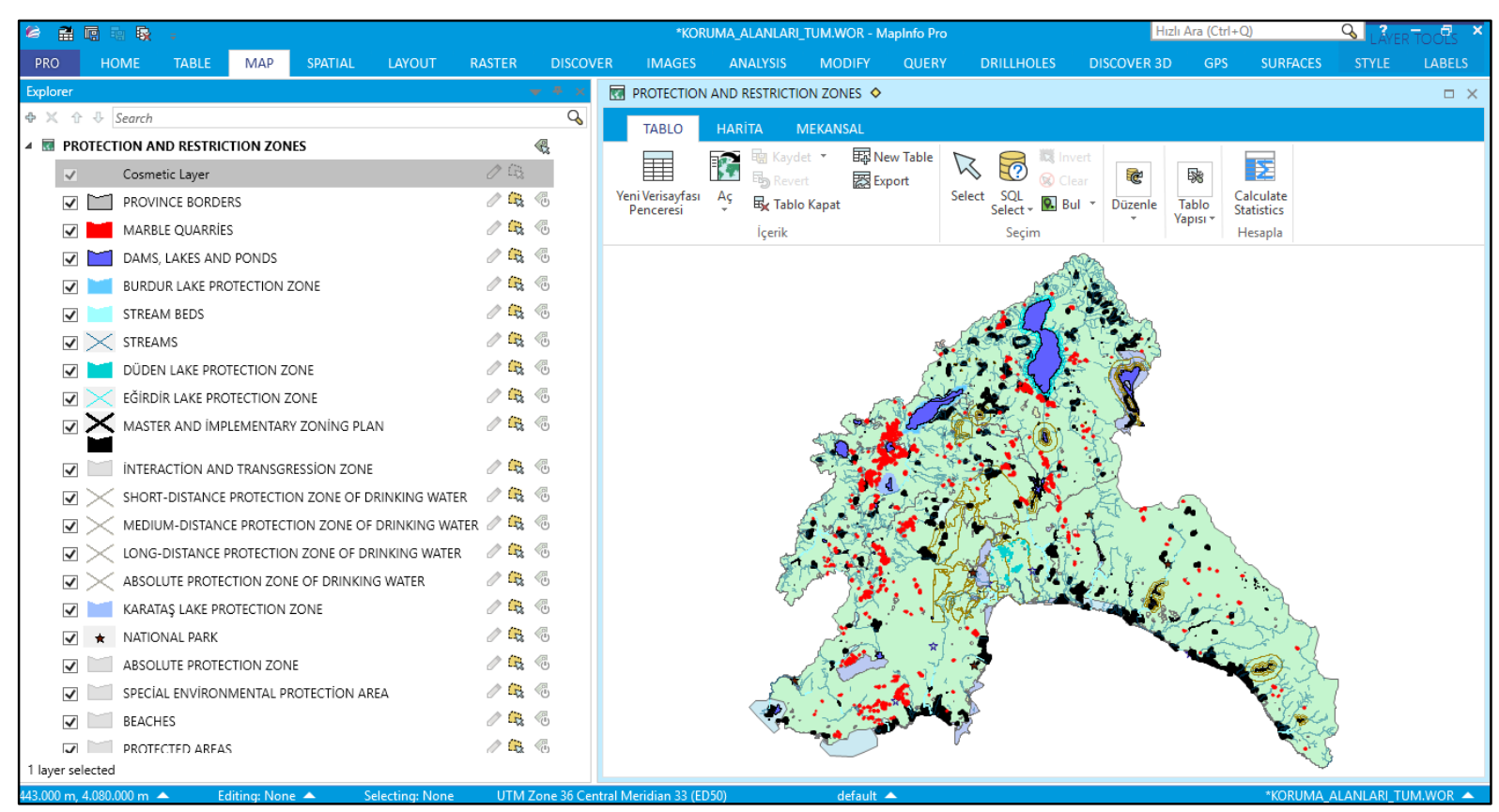

Figure 3. Protection sites of the chosen region identified in GIS 
In the study area as restriction areas; airport, coastline, tourism areas, road network, water resources, forest areas, land use capability classes, residential areas, fault formations, wildlife, areas to be protected agricultural area, trade and industrial areas, altitude and tourism areas were taken into consideration. Together with expert opinions, buffer protection distance definition is made to these areas. Also in some cases, the minimum/maximum acceptable distance, height and slope values are defined.

\subsection{Weighting of the Criteria}

The analytical network process method [27] is used to determine the priority weights of the criteria concerning expert opinions. The experts were at the stage of defining the criteria and determining their weight. While determining criteria weights, expert opinion forms were used in this process. While determining criteria weights, expert opinion forms were used in this process. The geometric averages of the evaluations of the experts according to the scale of 1-9 were taken and internal-external interactions between the criteria were defined. In this study, Super Decisions 2.8.0 package program was used to more easily calculate priority vectors and consistency ratios.

Three main categories; spatial criteria, environmental criteria and post mining specific criteria are defined with some detailed sub-criteria for each:

- Spatial criteria's sub-criteria are; residential area, tourism area, commercial support areas, and road network,

- Environmental criteria's sub-criteria are; water resources and wildlife,

- Post mining specific criteria's sub-criteria are; available flora, restrictive soil properties, soil drainage, fault formations, soil depth, elevation, slope, land use capability classification, and erosion grade.

The priority weights of the criteria that are effective for determining post-mining land use are obtained as a result of the binary comparisons made. Expert opinions are used to make binary comparisons of the criteria and to determine the dependencies in the network structure. A group decision was made to decide whether the main criteria and the sub criteria influenced the decision and whether the criterions had a dual interaction between them or the interaction was single or double-sided. As a result of the evaluations obtained from specialist academic staff and specialists (10 experts including; 1 city and regional planner, 1 mining engineer, 5 geology engineer, 1 geophysics engineer, 1 agriculture technician, 1 environmental engineer) working in decision-making positions in the various institutions, the decision-making matrices of the criteria have been created. At the stage of expert selections; academicians and inspectors who have studied the marble quarries in the study area and know the structure of the region have been taken into account. The consistency ratio is calculated to determine whether the decision maker is consistent in making comparisons between the criteria

$\mathrm{CI}=\frac{\lambda_{\max }+-n}{n-1}$,

where $\mathrm{CI}$ is the consistency index, $\lambda_{\max }$ is the maximum eigenvalue and $n$ is the order of the matrix. The local priority vector is calculated using the following equation

$A w=\lambda_{\max } w$,

where $A$ is the comparison matrix, $w$ is the eigenvector and $\lambda_{\max }$ is the $A$ 's maximum eigenvalue. As the evaluators indicate their preferences in binary comparison matrices, it is aimed to achieve group value by combining expert evaluations by using geometric average method. For this purpose, the collection of decision matrices has been applied

$A_{i j}^{\prime}=\left(\prod_{k=1}^{m} A_{i j}^{w_{i}}\right)^{\frac{1}{m}}$ 
where $A_{\mathrm{ij}}$ is the final binary comparison matrix, weights given by decision-makers and $m$ is the number of the decision-makers.

As a result of all the binary comparisons made, a supermatrix is obtained by placing the local priority vectors matrix to obtain the global priority values. The initial super matrices were constructed using the priority vectors obtained from the binary comparisons. Finally, the importance weightings of the obtained limit matrix and comparative decision criteria are determined

$W_{\mathrm{F}}=\operatorname{Lim}_{p \rightarrow \infty}\left(W_{I}\right)^{\mathrm{p}}$

Criteria weighting values obtained from expert opinions are given in the Table 4.

Table 4. Criteria weightings obtained by expert decisions

\begin{tabular}{|l|l|l|}
\hline \multirow{4}{*}{ Main Criteria } & Criteria & $\begin{array}{l}\text { Weighting } \\
\text { Value }\end{array}$ \\
\hline $\begin{array}{l}\text { Spatial Criteria } \\
\text { Consistency } \text { index } \\
0.022<0.1\end{array}$ & Settlement Areas & 0.331 \\
\cline { 2 - 3 } & Tourism Areas & 0.209 \\
\cline { 2 - 3 } & Commercial Support Areas & 0.147 \\
\cline { 2 - 3 } $\begin{array}{l}\text { Environmental Criteria } \\
\text { Consistency index }= \\
0.000<0.1\end{array}$ & Woad Network & 0.311 \\
\cline { 2 - 3 } & Water Resources & 0.683 \\
\cline { 2 - 3 } Specific Criteria of & Available Flora & 0.316 \\
\hline \multirow{4}{*}{$\begin{array}{l}\text { Post-Mining Area } \\
\text { Consistency index }\end{array}$} & Restrictive Soil Properties & 0.190 \\
\cline { 2 - 3 } & Soil Drainage & 0.095 \\
\cline { 2 - 3 } & Fault Formations & 0.093 \\
\cline { 2 - 3 } & Soil Depth & 0.071 \\
\cline { 2 - 3 } & Elevation & 0.096 \\
\cline { 2 - 3 } & Slope & 0.105 \\
\cline { 2 - 3 } & Land Use Capability Classification & 0.132 \\
\cline { 2 - 3 } & Erosion Grade & 0.084 \\
\hline
\end{tabular}

\subsection{Normalization of the Criteria}

The fuzzy logic membership functions of criteria are defined in the 0-1 mathematical range within the cells formed on the map layers and normalization is performed on the geographic information systems. In this context, there are several ways to create fuzzy membership functions. In environmental applications, there are two different but complementary approaches for grouping individuals into fuzzy sets or classes. The first one is a similarity-relation model, the other one is the semantic import model [28]. The semantic import model is used as the fuzzy logic approach in the study. The model is chosen because it is suitable for the structure of the study subject. In the process of classifying fuzzy memberships of criteria, sigmoidal shaped increasing [29], sigmoidal shaped decreasing [29], linear increasing [30,31] and linear decreasing [30,31] membership functions are used. Fuzzy membership functions used in this study are shown in Figure 4. 

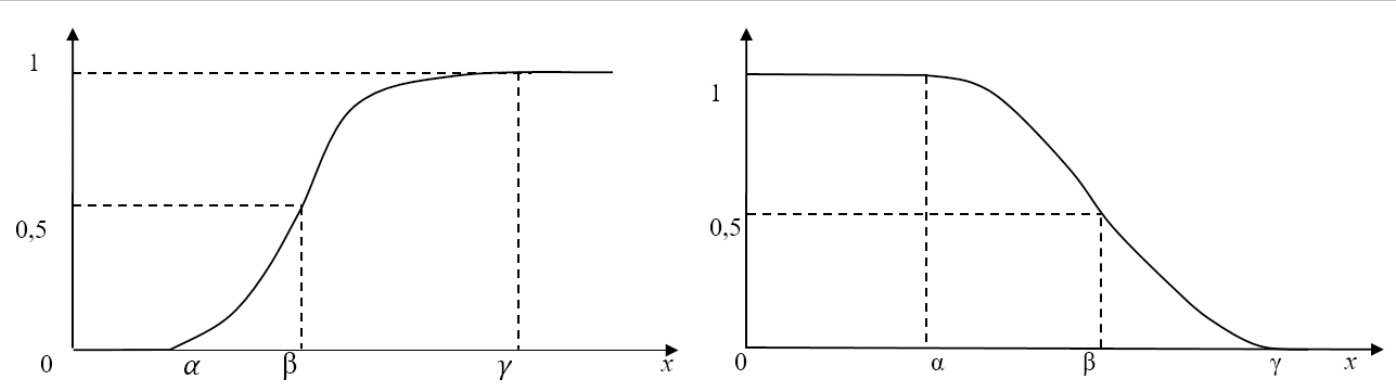

Sigmoidal shaped fuzzy membership function Sigmoidal shaped decreasing fuzzy membership function
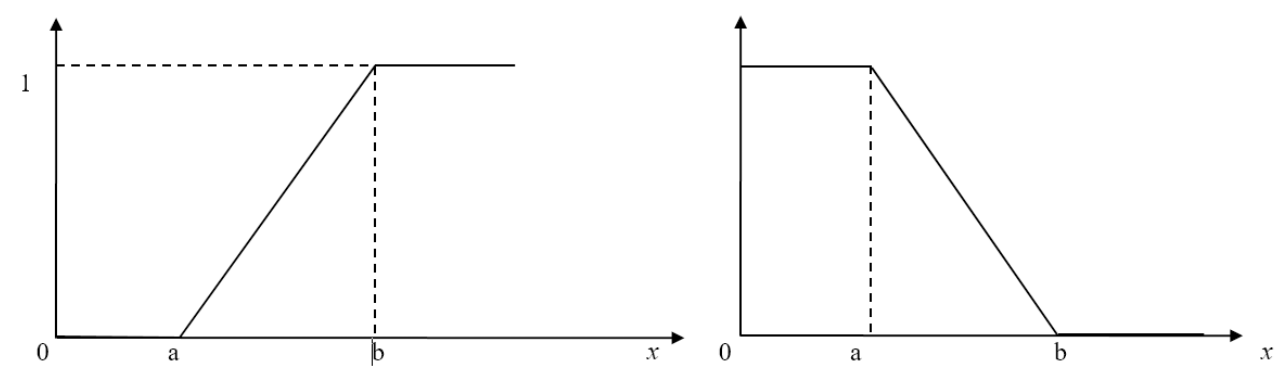

Linear increasing fuzzy membership function Linear decreasing fuzzy membership function

Figure 4. Fuzzy membership functions used in the study [27-29]

At this stage of the study; criteria normalization values of fuzzy logic membership functions to be evaluated in the 0-1 mathematical range are defined. In the process of defining the normalization of criteria values on the GIS, firstly the literature on the work done in this context has been taken into account and after those land use criteria and their normalization values were confirmed by expert opinion forms. In addition, in cases where the standardization values of the criteria evaluation cannot be made with mathematical equations, the values are manually determined as a result of the group decision. In this section, the parameters of fuzzy membership functions belonging to land use suitability characteristics, function classifications and the details of the mathematical equations used are stated. The parameters used for criteria normalization on the geographical information system are given in Table 5.

Table 5. Normalization parameters used for the criteria affecting land use alternatives

\begin{tabular}{|c|c|c|c|c|c|}
\hline \multirow{2}{*}{ Criteria } & \multicolumn{5}{|c|}{ Land Use Alternatives } \\
\hline & Agriculture & Afforestation & Recreation & Industrial Area & Landfill Area \\
\hline Slope & $0-30^{\circ}$ & $0-30^{\circ}$ & $0-24^{\circ}$ & $0-10^{\circ}$ & $0-20^{\circ}$ \\
\hline Elevation & $0-1,250 \mathrm{~m}$. & - & $0-2,000 \mathrm{~m}$. & $0-1,000 \mathrm{~m}$. & $800-1,000 \mathrm{~m}$. \\
\hline $\begin{array}{l}\text { Distance to } \\
\text { water } \\
\text { resources }\end{array}$ & $0-2,000 \mathrm{~m}$ & - & $30-3,000 \mathrm{~m}$. & $1,000-5,000 \mathrm{~m}$. & $300-1,000 \mathrm{~m}$. \\
\hline $\begin{array}{l}\text { Distance to } \\
\text { residential } \\
\text { areas }\end{array}$ & - & - & $250-10,000 \mathrm{~m}$. & $2,000-8,000 \mathrm{~m}$. & $\begin{array}{l}2,000-15,000 \\
\text { m. }\end{array}$ \\
\hline $\begin{array}{l}\text { Distance to } \\
\text { tourism areas }\end{array}$ & - & - & - & $\begin{array}{l}5,000-15,000 \\
\mathrm{~m} .\end{array}$ & $\begin{array}{l}5000-15,000 \\
\text { m. }\end{array}$ \\
\hline $\begin{array}{l}\text { Distance to } \\
\text { road network }\end{array}$ & $100-4,000 \mathrm{~m}$. & - & $0-15,000 \mathrm{~m}$. & $1,500-5,000 \mathrm{~m}$. & $200-10,000 \mathrm{~m}$. \\
\hline $\begin{array}{l}\text { Distance to } \\
\text { commercial } \\
\text { support areas }\end{array}$ & - & - & - & $0-7,500 \mathrm{~m}$. & - \\
\hline $\begin{array}{l}\text { Distance to } \\
\text { wild }\end{array}$ & - & - & $\begin{array}{l}5,000-30,000 \\
\text { m. }\end{array}$ & $\begin{array}{l}5,000-15,000 \\
\text { m. }\end{array}$ & $\begin{array}{l}5,000-15,000 \\
\text { m. }\end{array}$ \\
\hline
\end{tabular}




\begin{tabular}{|c|c|c|c|c|c|}
\hline $\begin{array}{l}\text { Distance to } \\
\text { fault lines }\end{array}$ & - & - & $100-2,000 \mathrm{~m}$. & $250-1,000 \mathrm{~m}$. & $60-2,000 \mathrm{~m}$. \\
\hline $\begin{array}{l}\text { Land use } \\
\text { capability } \\
\text { classification }\end{array}$ & $\begin{array}{l}\text { I. Class: } 1 \\
\text { II. Class:0.75 } \\
\text { III. Class:0.50 } \\
\text { IV. Class:0.25 }\end{array}$ & $\begin{array}{l}\text { VII. Class: } 1 \\
\text { VI. Class:0.75 } \\
\text { V. Class:0.50 } \\
\text { IV. Class:0.25 }\end{array}$ & $\begin{array}{l}\text { VII. Class: } 1 \\
\text { VI. Class:0.75 } \\
\text { V. Class:0.50 } \\
\text { VIII. Class: } \\
0.25\end{array}$ & $\begin{array}{l}\text { VIII. Class: } 1 \\
\text { VII. Class:0.75 } \\
\text { VI. Class:0.50 } \\
\text { V Class: } 0.25\end{array}$ & $\begin{array}{l}\text { VIII. Class: } 1 \\
\text { VII. Class:0.75 } \\
\text { VI. Class:0.50 } \\
\text { V Class: } 0.25\end{array}$ \\
\hline $\begin{array}{l}\text { Degree of } \\
\text { erosion }\end{array}$ & $\begin{array}{l}\text { Low: } 1 \\
\text { Moderate: } 0.75 \\
\text { High: } 0.50 \\
\text { Extreme: } 0.25\end{array}$ & $\begin{array}{l}\text { Extreme: } 1 \\
\text { High: } 0.75 \\
\text { Moderate: } 0.50 \\
\text { Low: } 0.25\end{array}$ & $\begin{array}{l}\text { Low: } 1 \\
\text { Moderate: } 0.50 \\
\text { High: } 0.25 \\
\text { Extreme: } 0\end{array}$ & $\begin{array}{l}\text { Low: } 1 \\
\text { Moderate: } 0.50 \\
\text { High: } 0 \\
\text { Extreme: } 0\end{array}$ & $\begin{array}{l}\text { Low: } 1 \\
\text { Moderate: } 0.75 \\
\text { High: } 0.50 \\
\text { Extreme: } 0.25\end{array}$ \\
\hline $\begin{array}{l}\text { Restrictive soil } \\
\text { characteristics }\end{array}$ & $\begin{array}{l}\text { Non-restrictive: } 1 \\
\text { Restrictive: } 0\end{array}$ & - & $\begin{array}{l}\text { Non-restrictive: } \\
1 \\
\text { Restrictive: } 0\end{array}$ & $\begin{array}{l}\text { Restrictive: } 1 \\
\text { Non-restrictive: } \\
0\end{array}$ & $\begin{array}{l}\text { Restrictive: } 1 \\
\text { Non-restrictive: } \\
0\end{array}$ \\
\hline Soil drainage & $\begin{array}{l}\text { Non-drainage } \\
\text { problem: } 1 \\
\text { Drainage } \\
\text { problem: } 0.33\end{array}$ & $\begin{array}{l}\text { Non-drainage } \\
\text { problem: } 1 \\
\text { Drainage } \\
\text { problem: } 0.33\end{array}$ & $\begin{array}{l}\text { Non-drainage } \\
\text { problem: } 1 \\
\text { Drainage } \\
\text { problem: } 0.33\end{array}$ & $\begin{array}{l}\text { Non-drainage } \\
\text { problem: } 1 \\
\text { Drainage } \\
\text { problem: } 0\end{array}$ & - \\
\hline Soil depth & $\begin{array}{l}>90 \mathrm{~cm} .: 1 \\
50-90 \mathrm{~cm} .: 0.75 \\
20-50 \mathrm{~cm} .: 0.50 \\
0-20 \mathrm{~cm} .: 0.25\end{array}$ & $\begin{array}{l}>90 \mathrm{~cm} .: 1 \\
50-90 \mathrm{~cm} .: 0.75 \\
20-50 \mathrm{~cm} .: 0.50 \\
0-20 \mathrm{~cm} .: 0.25\end{array}$ & - & - & - \\
\hline $\begin{array}{l}\text { Available } \\
\text { Flora }\end{array}$ & $\begin{array}{l}\text { Non-forest area: } 1 \\
\text { Forest area: } 0\end{array}$ & $\begin{array}{l}\text { Forest area: } 1 \\
\text { Non-forest } \\
\text { area: } 0\end{array}$ & $\begin{array}{l}\text { Forest area: } 1 \\
\text { Non-forest } \\
\text { area: } 0\end{array}$ & $\begin{array}{l}\text { Non-forest } \\
\text { area: } 1 \\
\text { Forest area: } 0\end{array}$ & $\begin{array}{l}\text { Non-forest } \\
\text { area:1 } \\
\text { Forest area: } 0\end{array}$ \\
\hline
\end{tabular}

Some fuzzy membership functions for criteria standardization and related mathematical equations are given in Table 6.

Table 6. Fuzzy logic membership functions for normalization parameters [27-29]

\begin{tabular}{|c|c|c|c|c|}
\hline Land Use & $\begin{array}{l}\text { Criteria } \\
\text { (unit) }\end{array}$ & $\begin{array}{l}\text { Fuzzy Model } \\
\text { Function }\end{array}$ & Control Points (0-1) & Mathematical equation \\
\hline $\begin{array}{l}\text { Agricultural } \\
\text { area }\end{array}$ & $\begin{array}{l}\text { Distance to } \\
\text { water } \\
\text { resources } \\
\text { (m.) }\end{array}$ & Linear decrease & $\mathrm{a}: 0 ; \mathrm{b}: 2,000$ & $A(x)=\left\{\begin{array}{l}1 \\
-(x-b) / b-a \\
0\end{array}\right.$ \\
\hline Afforestation & Slope $\left(^{\circ}\right)$ & $\begin{array}{l}\text { Sigmoidal } \\
\text { shaped increase }\end{array}$ & $\alpha: 0 ; \beta: 15 ; \gamma: 30$ & $S(x ; \alpha, \beta, \gamma)=\left\{\begin{array}{lr}0 & x \in[-\infty, \alpha] \\
2[(x-\alpha) / \gamma-\alpha]^{2} & x \in[\alpha, \beta] \\
1-2[(x-\gamma) /(\gamma-\alpha)]^{2} & x \in[\beta, \gamma] \\
1 & x \in[\gamma,+\infty]\end{array}\right.$ \\
\hline $\begin{array}{l}\text { Recreational } \\
\text { area }\end{array}$ & $\begin{array}{l}\text { Distance to } \\
\text { wild life (m.) }\end{array}$ & Linear increase & $\mathrm{a}: 5,000 ; \mathrm{b}: 30,000$ & $A(x)=\left\{\begin{array}{l}0 \\
x-a / b-a \\
1\end{array}\right.$ \\
\hline $\begin{array}{l}\text { Industrial } \\
\text { Area }\end{array}$ & $\begin{array}{l}\text { Distance to } \\
\text { residential } \\
\text { area }(\mathrm{m} .)\end{array}$ & $\begin{array}{l}\text { Sigmoidal } \\
\text { shaped } \\
\text { decrease }\end{array}$ & $\begin{array}{l}\alpha: 2,000, \beta: 5,000 \\
\gamma: 8,000\end{array}$ & $S(x ; \alpha, \beta, \gamma)=\left\{\begin{array}{lr}1 & x \in[-\infty, \alpha] \\
1-2[(x-\alpha) / \gamma-\alpha]^{2} & x \in[\alpha, \beta] \\
2[(x-\gamma) /(\gamma-\alpha)]^{2} & x \in[\beta, \gamma] \\
0 & x \in[\gamma,+\infty]\end{array}\right.$ \\
\hline Landfill area & $\begin{array}{l}\text { Distance to } \\
\text { water } \\
\text { resources } \\
(\mathrm{m} .)\end{array}$ & Linear increase & $\mathrm{a}: 300 ; \mathrm{b}: 1,000$ & $A(x)=\left\{\begin{array}{l}0 \\
x-a / b-a \\
1\end{array}\right.$ \\
\hline
\end{tabular}




\section{CASE STUDY}

The study is limited to marble mining activity in the region where Antalya, Burdur, and Isparta provinces (Turkey) are located. It is in the western Mediterranean region where marble production activities are concentrated (Figure 5). According to the data of 2017, the study area constitutes $3.79 \%$ of Turkey's population with 3,063,005 people [32]. Especially Antalya province is one of the most visited touristic resorts of Turkey.

In Turkey, there are rich marble formations with 5,161,000,000 $\mathrm{m}^{3}$ reserve potential [33]. Turkey's total amount of marble export is approximately 825,936 (1000\$) and import share in the World market is approximately $34.71 \%$. [34]. Looking at the distribution by region; there are 2,568 registered marble and other natural stone mining licenses in Turkey. In the study area, there are 714 active mining fields in the marble and other natural stones group (approximately $23.30 \%$ of Turkey's total) [35]. The total number of licenses is subject to change due to new license requests and license cancellation procedures.

Marble mines of the region are an important commercial activity for foreign exports due to the high demand potential in the international markets and its proximity to the port of Antalya. The distribution of the marble quarry areas within the study area is plotted on a thematic map (Figure 6).

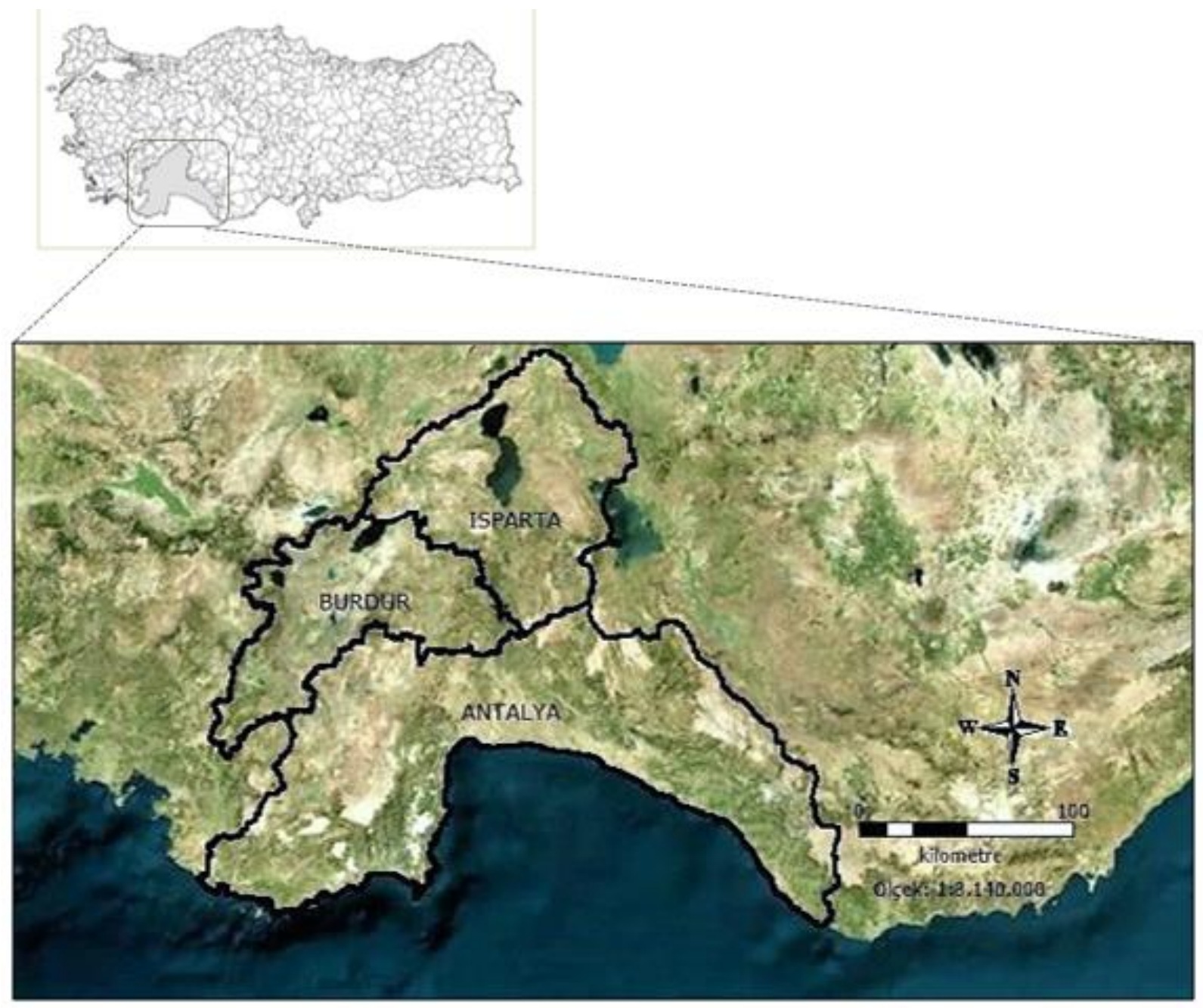

Figure 5. Study area 


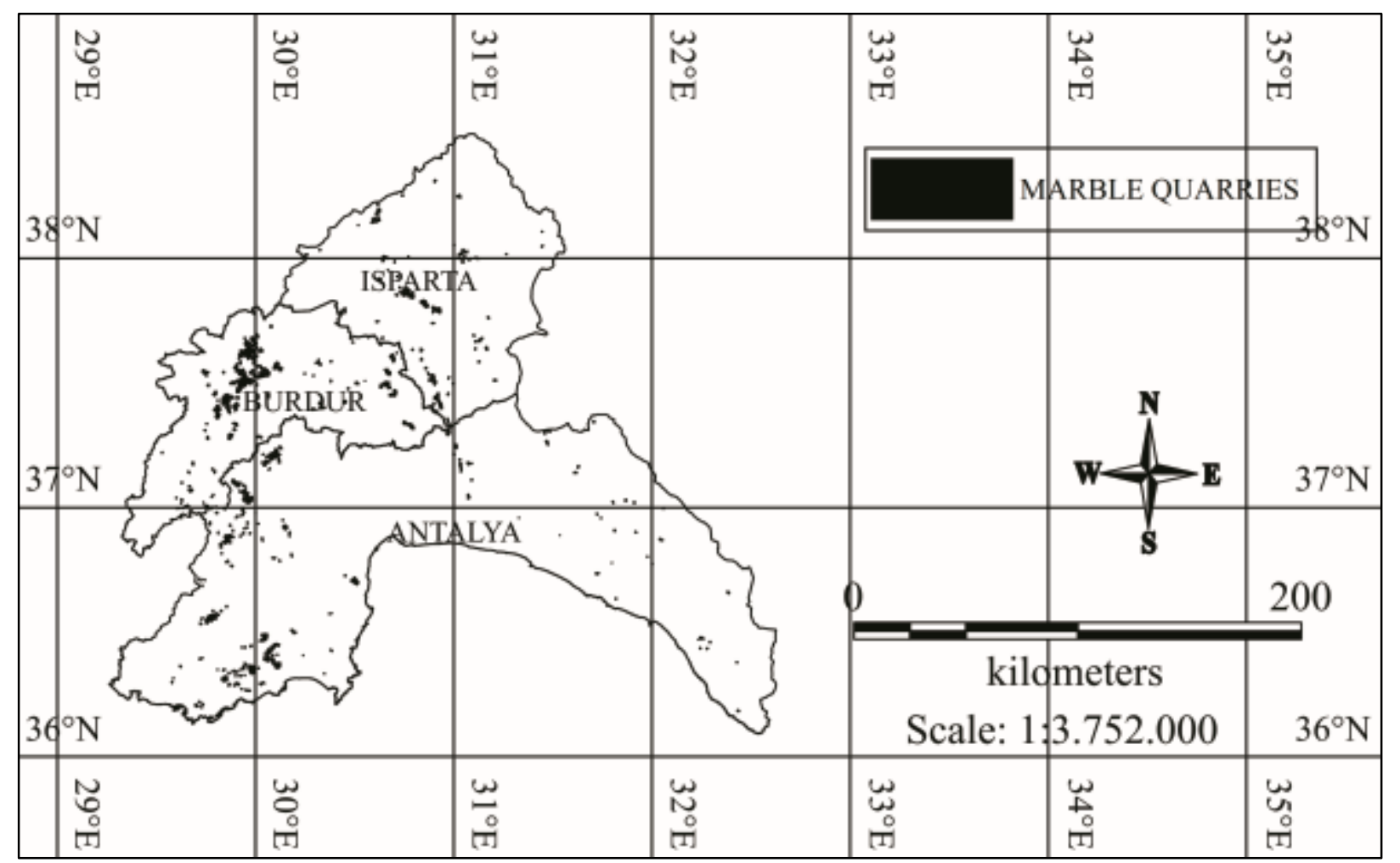

Figure 6. Marble quarry locations in the selected study area

\subsection{Suitability Scores of Land Use Alternatives for Post-Mining Areas}

At the land utilization determination stage of each marble quarry, the highest cell density of land use suitability type is taken into account. Post-mining land use allocation plans are decided for a total of 715 marble quarry licenses. The generated model has 374,492 cells (each cell is $30 \times 30 \mathrm{~m}$ dimension) and 15 different criteria map layers. As a result of the application of the model; 29,505.20 hectares of the area including 715 marble areas is allocated to post-mining land use suitability plans (Table 7).

Table 7. Land use suitability planning of marble quarries in the study area

\begin{tabular}{|l|l|l|l|l|}
\hline Land use types & Burdur & Isparta & Antalya & Total \\
\hline Agriculture Area Land Suitability & 28 & 6 & 18 & 52 \\
\hline Nr of quarries & 28 & 116,736 & 691,905 & $2,036.15$ \\
\hline Area (ha) & $1,227.51$ & 83 & 43 & 250 \\
\hline Afforestation Area Land Suitability & $9,815.34$ \\
\hline Nr of quarries & 124 & $2,884.02$ & $1,566.65$ & \\
\hline Area (ha) & $5,364.67$ & \multicolumn{5}{|l|}{} \\
\hline Recreational area Land Suitability & 71 & 134 & 248 \\
\hline Nr of quarries & 73 & $1,655.15$ & $5,030.03$ & $9,525.27$ \\
\hline Area (ha) & $2,840.09$ & 2 & 8 & 11 \\
\hline Industrial Development Area Suitability \\
\hline Nr of quarries & 1 & 250,92 & 292,63 \\
\hline Area (ha) & 23,733 & 17,982 & 250,92 \\
\hline Landfill Area Suitability & 68 & 15 & 71 \\
\hline Nr of quarries & $3,503.25$ & 488,004 & $3,844.55$ & $7,835.80$ \\
\hline Area (ha) &
\end{tabular}


The model results give the best option among the alternative land use classes. According to the results;

- a total of 9,815.34 hectares of area (approximately $34.96 \%$ of total) including 250 marble quarries are suitable for afforestation usage,

- a total of 9,525.27 hectares of area (approximately $34.68 \%$ of total) including 248 marble quarries are suitable for recreation land usage,

- a total of 7,835.80 hectares of area (approximately $21.54 \%$ of total) including 154 marble quarries are suitable for landfill area usage,

- a total of 2,036.15 hectares of area (approximately $7.27 \%$ of total) including 52 marble quarries are suitable for agricultural land usage, and

- a total of 292.63 hectares of area (approximately $1.54 \%$ of total) including 11 marble quarries are suitable for industrial development usage.

Land use suitability planning of post-mining areas in the study area are stated in Figure 7.

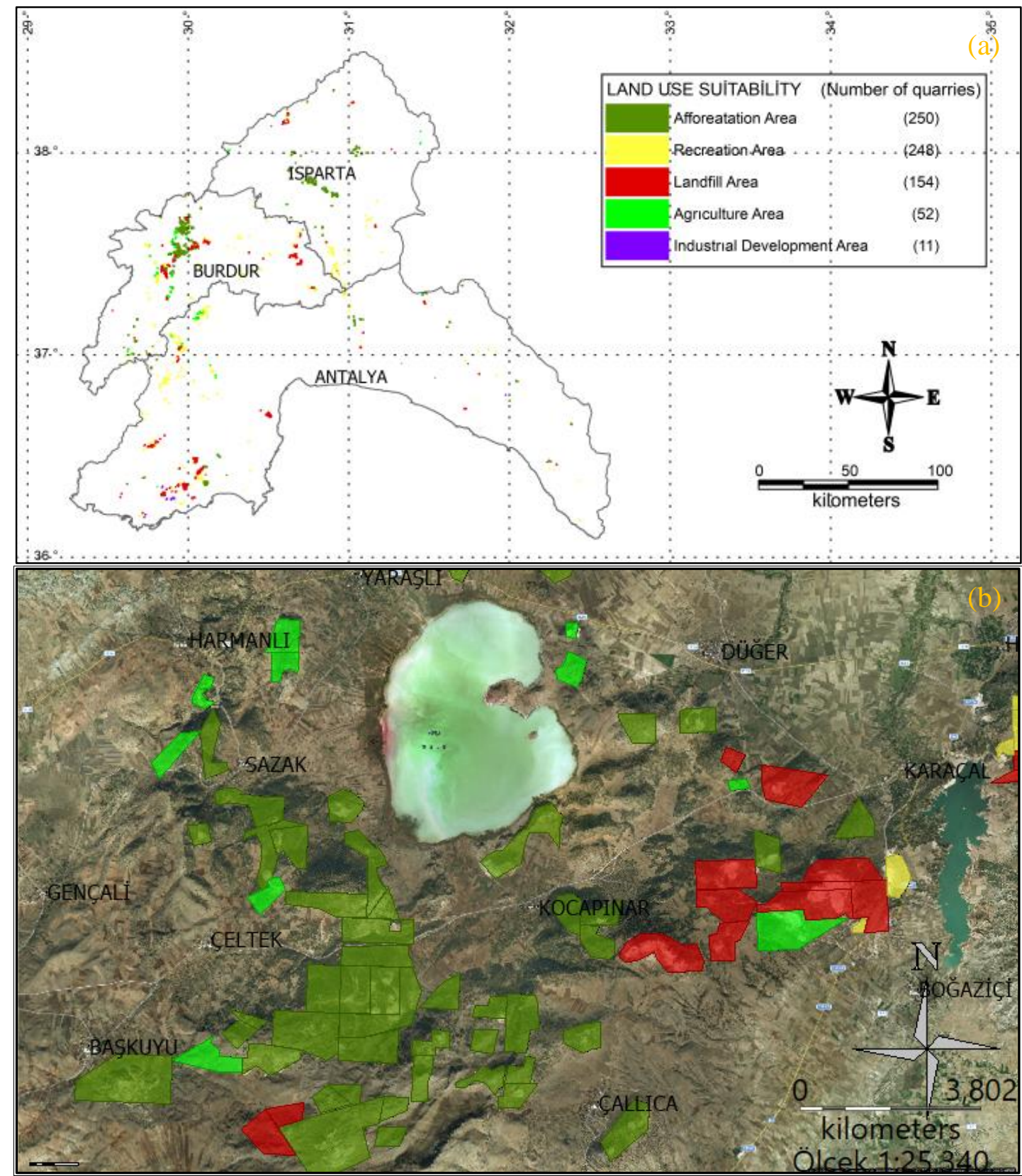

Figure 7. a) Land use suitability planning of post-mining areas in the study area b) Close view of an example from a model application area 


\section{CONCLUSION}

Making the systematic land suitability planning of mining areas is important for preventing environmental problems and accidents that may occur. In this context, establishing a systematic in planning will provide efficiency in terms of temporal and operational scope for identifying environmental problems and solving them. In this study, a systematic approach to landscape reclamation planning has been developed to minimize the adverse environmental impacts that may have been experienced in abandoned mining areas. The main findings of the study can be summarized as;

- Post mining land use alternatives (agricultural area, afforestation area, recreation area, industrial development area and landfill area) are determined through a detailed literature survey.

- A land use suitability model is developed as a decision support tool by using GIS, multi-criteria decision making method and fuzzy logic method.

- The study area is represented in many map layers stored in a GIS environment.

- Some absolute protection and restriction zones are taken into consideration on which none of the defined land use alternatives can be suggested.

- An effective set of criteria is defined for determining the most suitable land use type in the study area. The criteria in three main categories; spatial criteria, environmental criteria, specific post mining area criteria and their sub-criteria helped to evaluate the study area both in qualitative and quantitative ways. These criteria have been weighted within the concept of the study.

- Normalization of the criteria is executed by fuzzy logic membership functions.

- The prepared thematic maps can give a better visual effect to express the spatial distribution of each "most appropriate" land use alternative for post mining activities of marble mines in the study area.

- The developed model can be used in any other region for land use decision of post mining areas after preparing the necessary database in the required format taking account of regional structure.

The relatively high score of the area use type determined by the implementation of the model is not only effective in determining the suitability of the land use. It is decided that the result is not suitable if it falls within the restriction and protection areas. It is seen that some criteria are relatively less effective when the current structure of the region is considered by the experts. As a result of the planning; agricultural land, afforestation area, recreation area, industrial development area and landfill area usage types were determined. Criteria must be determined by the experts who are competent in decision making in the determined region. It is possible to apply the model mentioned in this study according to different mining group and a different location. It is possible to apply the model created in this study to different mining groups and in different locations.

\section{CONFLICTS OF INTEREST}

No conflict of interest was declared by the authors.

\section{REFERENCES}

[1] FLMPA, "Federal land policy and management act USA", U.S. Department of the Interior, Bureau of Land Management and Office of the Solicitor, Office of Public Affairs, Washington, D.C., 69-78, (1976).

[2] SMCRA, "Surface mining control and reclamation act public law 95-87 USA", December 31: 251-263, (1977).

[3] AEPG, "Best practice environmental management in mining, rehabilitation and revegetation", Australian Environment Protection Agency Department of Environment, Australia, Canberra, (1995).

[4] Zolekar, R. B., Bhagat, V. S., "Multi-criteria land suitability analysis for agriculture in hilly zone: Remote sensing and GIS approach", Computers and Electronics in Agriculture, 118: 300-321, (2015). 
[5] Maryati, S., "Land Capability Evaluation of Reclamation Area in Indonesia Coal Mining Using LCLP Software", Procedia Earth and Planetary Science, 6: 465-473, (2013).

[6] Akinci, H., Ozalp, A. Y., Turgut, B., "Agricultural land use suitability analysis using GIS and AHP technique", Computers and Electronics in Agriculture, 97: 71-82, (2013).

[7] Fontana, V., Radtke, A., Fedrigotti, V. B., Tappeiner, U., Tasser, E., Zerbe, S., Buchholz, T., "Comparing land-use alternatives: Using the ecosystem services concept to define a multi-criteria decision analysis", Ecological Economics, 93: 128-136, (2013).

[8] Piran, H., Maleknia, R., Akbari, H., Soosani, J., Karami, O., "Site selection for local forest park using analytic hierarchy process and geographic information system (Case study: Badreh County)", International Research Journal of Applied and Basic Sciences, 6(7): 930-935, (2013).

[9] Dubovyk, O., Menz, G., Khamzina, "A land suitability assessment for afforestation with Elaeagnus angustifolia L. in degraded agricultural areas of the lower Amudarya river basin", Land Degradation \& Development, 27(8): 1831-1839, (2016).

[10] Wang, J., Zhao, F., Yang, J., Li, X., "Mining Site Reclamation Planning Based on Land Suitability Analysis and Ecosystem Services Evaluation: A Case Study in Liaoning Province, China", Sustainability, 9(6):890, (2017).

[11] Mosadeghi, R., Warnken, J., Tomlinson, R., Mirfenderesk, H., "Comparison of Fuzzy-AHP and AHP in a spatial multi-criteria decision making model for urban land-use planning", Computers, Environment and Urban Systems, 49: 54-65, (2015).

[12] Akinci, H., Ozalp, A. Y., Turgut, B., "Agricultural land use suitability analysis using GIS and AHP technique", Computers and Electronics in Agriculture, 97: 71-82, (2013).

[13] Sobhanardakani, S., Seied, M. M., "Environmental Valuation of Industrial Estates Location Case Study: Kohgilouyeh \& Boyerahmad Province", International Journal of Agriculture and Crop Sciences, 5 (18): 2147-2162, (2013).

[14] Liu, R., Zhang, K., Zhang, Z., Borthwick, A. G., "Land-use suitability analysis for urban development in Beijing", Journal of Environmental Management, 145: 170-179, (2014).

[15] Masoumi, I., Naraghi, S., Rashidi-Nejad, F., Masoumi, S., "Application of fuzzy multi-attribute decision-making to select and to rank the post-mining land-use", Environmental Earth Sciences, 72(1): 221-231, (2014).

[16] Palogos, I., Galetakis, M., Roumpos, C., Pavloudakis, F., "Selection of optimal land uses for the reclamation of surface mines by using evolutionary algorithms", International Journal of Mining Science and Technology, 27(3): 491-498, (2017).

[17] Salemi, M., Hejazi, R., "A GIS-Based suitability analysis for siting a solid waste in an urban area", International Journal of Human Capital in Urban Management, 2(1): 57-68, (2017).

[18] Isalou, A. A., Zamani, V., Shahmoradi, B., Alizadeh, H., "Landfill site selection using integrated fuzzy logic and analytic network process (F-ANP)", Environmental Earth Sciences, 68(6): 1745-1755. (2013).

[19] Eskandari, M., Homaee, M., Mahmoodi, S., Pazira, E., Van Genuchten, M. T., “Optimizing landfill site selection by using land classification maps", Environmental Science and Pollution Research, 22(10): 7754-7765, (2015). 
[20] Rahmat, Z. G., Niri, M. V., Alavi, N., Goudarzi, G., Babaei, A. A., Baboli, Z., Hosseinzadeh, M., "Landfill site selection using GIS and AHP: A case study: Behbahan, Iran", KSCE Journal of Civil Engineering, 21(1): 111-118, (2017).

[21] Khan, D., Samadder, S. R., “A simplified multi-criteria evaluation model for landfill site ranking and selection based on AHP and GIS", Journal of Environmental Engineering and Landscape Management, 23(4): 267-278, (2015).

[22] Motlagh, Z. K., Sayadi, M. H., "Siting MSW landfills using MCE methodology in GIS environment (Case study: Birjand plain, Iran)", Waste Management, 46: 322-337, (2015).

[23] Eskandari, M., Homaee, M., Mahmoodi, S., Pazira, E., Van Genuchten, M. T., "Optimizing landfill site selection by using land classification maps", Environmental Science and Pollution Research, 22(10): 7754-7765, (2015).

[24] Malczewski, N., “GIS and Multcriteria Decision Analysis”, Wiley, New York, (1999).

[25] Hwang, C. L., Yoon, K., "Multiple criteria decision making", Lecture Notes in Economics and Mathematical Systems, Springer-Verlag, (1981).

[26] Greene, R., Devillers, R., Lutjer, J. E., Eddy, B. G., "GIS Based Multiple Criteria Decision Analysis", Geography Compass, 56: 412-432, (2011).

[27] Saaty, T. L., "Decision making with Dependence and Feedback: The Analytical Network Process", RWS Publications, Pittsburg, (1996).

[28] McBratney, A. B., Odeh, I. O. A., "Application of fuzzy sets in soil science: fuzzy logic, fuzzy measurements and fuzzy decisions", Geoderma, 77: 85-113, (1997).

[29] Novak, V., "Fuzzy logic: Applications to natural language", in: Shapiro, S.C.(ed) Encyclopedia of Artificial Intelligence (Second edition), New York: John Wiley \& Sons, (1992)

[30] Wu, F., "Simulating urban encroachment on rural land with fuzzy-logic-controlled cellular automata in a geographical information system", Journal of Environmental Management, 53, 293-308, (1998).

[31] Rickel, B. W., Anderson, B., Pope, R., "Using fuzzy systems, object-oriented programming and GIS to evaluate wildlife habitat", AI Applications: 12, 31-40, (1998).

[32] TUIK, "Provinces, the migration, net migration and migration rate, general population censuses, Research Results", Turkish Statistical Institute, Ankara, (2019).

[33] MTA, General Directorate of Mineral Research and Exploration, http://www.mta.gov.tr/v3.0/bilgimerkezi/maden-rezervleri, (2013).

[34] ITC, Trade statistics for international business development, https://trademap.org/Index.aspx, (2016).

[35] MAPEG, General Directorate of Mining and Oil works, http://www.migem.gov.tr/istatistik.aspx, (2018). 